\title{
Extraction of Uronic Acid From Sargassum crassifolium and Its Feeding Effects On The Eggs Production and Quality of Lohmann Chicken Eggs
}

\author{
Veybe Gresje Kereh*1, Ivonne Maria Untu ${ }^{1}$, Marie Najoan ${ }^{1}$, T. Lumi ${ }^{2}$ \\ ${ }^{1}$ Departement of Feed and Animal Nutrition, Faculty of Animal Science, \\ Sam Ratulangi University, Jln Kampus Bahu, Manado, 95115 \\ ${ }^{2}$ Departement of Social and Economic, Faculty of Animal Science, \\ Sam Ratulangi University, Jln Kampus Bahu, Manado, 95115 \\ *Email korespondensi: veybekereh@gmail.com
}

(Diterima 02-07-2020; disetujui 30-09-2020)

\begin{abstract}
The use of antibiotics in chicken feed is currently banned because it can cause resistance to pathogenic bacteria and cause residues in products. This study aimed to see the effect of drinking water containing uronic acid extracted from Sargassum crassifolium (S. crassifolium) on the physical and chemical quality of Lohmann chicken eggs. One hundred and twenty laying hens were divided into 2 groups: (1) chickens given commercial feed containing antibiotics and (2) feed without additional antibiotics. The chickens were randomly assigned to one of the 5 brown seaweed supplementation treatments in drinking water $\mathrm{A} 1=0.0 \%$ S.crassifolium (control); $\mathrm{A} 2=2.5 \%$ S.crassifolium; A3 $=5.0 \%$ S.crassifolium; A4 $=7.5 \%$ S.crassifolium; A5 $=10.0 \%$ S.crassifolium. The study used a completely randomized factorial design of 5 treatments, 2 factors, and 3 replications. Each replication consisted of 6 heads of laying hens. There were no differences between treatments on the performance of laying hens (egg production, egg weight, egg mass, feed conversion); physical quality (eggshell, egg yolk, egg white, shell thickness, egg yolk, Haugh unit, egg index) and chemistry (superoxide dismutase production, thiobarbituric acid reactive substances (TBARS) and Lohmann chicken egg cholesterol) but there was a difference in feed intake. The uronic acid extracted from $S$. crassifolium has not been able to increase the production and quality of Lohmann chicken eggs.
\end{abstract}

Keywords: lohmann chicken, quality of eggs, Sargassum crassifolium, uronic acid

\section{INTRODUCTION}

Sargassum crassifolium (S. crassifolium) belongs to the Phaeophyceae (brown algae) class, which has true roots, stems and leaves (Yenusi $e t$ al., 2014), varied forms and mostly brown or blonde coloration (these colours do not change even with drying) (Merdekawati \& Susanto, 2009). Brown seaweed (S. crassifolium) contains major components including sugar, sulfate and uronic acid and has been shown to play an antiviral and antibacterial role (Mandal et al., 2007). S. Crassifolium contains polysaccharides (Merdekawati \& Susanto, 2009), polyphenols and carotenoids (Wijesinghe \& Jeon, 2011). Polysaccharides play a role in reducing blood lipid, and cholesterol levels, they aid in digestion, and they have antithrombotic, anticancer, antioxidant (Zhao et al., 2005), antiproliferative (uncontrolled cell division), anti-inflammatory (Shiratori et al., 2005), and anticoagulants properties (Chandia \& Matsuhiro, 2008). In particular, many researchers report the availability of various antioxidants in seaweed, such as polysaccharides, dietary fibre, minerals, proteins, amino acids, vitamins, polyphenols, and carotenoids (Burtin, 2003).

Seaweed availability is quite abundant and has not been optimally utilized thus, it can be processed into animal feed ingredients. As stated by Anggadiredja et al. (1996) and March et al. (2013) seaweed is a natural source of non-starch polysaccharides that contains many crude fibres and its bioactive factors affect the digestive process resulting in changes in microflora in the caecum and the efficient use of nutrients by laying hens (Anggadiredja et al., 1996; March et al., 2013). 
However, microbes such as viruses or bacteria in air, food or water have the potential to harm livestock. Bacteria, including the Salmonella sp. group, often contaminate chickens from the surrounding environment, to hatching, to growth and post-harvest, and to the consumers' hands (Gantois et al., 2009). In addition to affecting the health of livestock, these bacteria will also affect the safety aspects of meat or egg products that will be consumed by humans. Several attempts have been made to overcome this, such as vaccination, sanitation or antibiotic use. This effort is useful but has limitations, for example some of antibiotic resistant to strains of bacteria (Devegowda et al., 1997). Antibiotics are used to inhibit the development of pathogens (Farhad \& Farida, 2011; Teteh et al., 2016).. However, currently the use of antibiotics in feed has been restricted because it tends to increase the resistance of pathogen bacteria (Abdulhasan, 2018; Santoso et al., 2018), therefore antibiotic alternatives from natural ingredients are needed in feed formulas (Abdulhasan, 2018; Abaza, 2007; Winsisch et al., 2008; Abbas, 2013; Aqil, 2016) to produce safe, healthy and competitive meat and egg products (Mahfuz et al., 2017; Voemesse et al., 2018). The use of $S$. crassifolium with uronic acid content may become an alternative substitute for antibiotics. The use of $S$. crassifolium as a potential seaweed additive in feed ingredients, especially feed additives is still not reported. Therefore this study aimed to examine the effects of uronic acid extracted from $S$. crassifolium as an antibiotic substitute on the production and quality of Lohmann chicken eggs.

\section{MATERIALS AND METHODS}

\section{Research Material}

This study used 120 Lohmann strains aged 22 weeks and brown seaweed (S.crassifolium). The commercial feeds used in the study were feed containing antibiotics and feed without additional antibiotics. Supplementation of brown seaweed ( $S$. crassifolium) extract was $0,2.5,5.0,7.5$ and $10.0 \%$ given in drinking water. The nutrient content of the feed is presented in Table 1. The cage used was an individual battery system (size $35 \times 36 \times 42 \mathrm{~cm}$ ) equipped with a feeding area, drinking water and lights (16L/8D lighting system). The chickens were adapted to the provisional feed for 1 month and drinking water for 1 week before treatment began. The Chicken maintenance was carried out for 3 (three) months.
Table 1. Nutrient content of feed

\begin{tabular}{lc}
\hline & Nutrient composition \\
\hline Dry mater $(\%)$ & 93.02 \\
Ash $(\%)$ & 10.77 \\
Crude protein (\%) & 18.12 \\
Ether extract (\%) & 5.63 \\
Crude fibre (\%) & 6.16 \\
BETN (\%) & 52.34 \\
Gross energy (Kcal/kg) & 37.34 \\
Calcium $(\%)$ & 5.85 \\
Phosphor $(\%)$ & 0.71 \\
\hline
\end{tabular}

\section{Preparation of Seaweed Extract}

Seaweed extract was made by mixing 100 grams of dried seaweed with ethanol $(90 \%)$ (5:1), stirred for 3 hours and allowed to stand for 24 hours at room temperature and then concentrated used rotary evaporator at $50^{\circ} \mathrm{C}$ about 4 hours.

\section{Feeding Trial}

One hundred and twenty Lohmann strains aged 18 weeks were divided into 2 groups: (1) chickens given commercial feed containing antibiotics and (2) chickens given feed without additional antibiotics. The chickens were randomly assigned to one of the 5 brown seaweed supplementation treatments: $(0,2.5,5.0,7.5$ or $10 . \%)$ in the drinking water. Feed and drinking water were given ad libitum in the morning ( 07.00 WIB) and afternoon (17.00 WIB).

\section{Variables observed}

The variables observed in this study included the following: the performance of laying hens (feed consumption ( $\mathrm{g} / \mathrm{head} / \mathrm{day}$ ), daily egg production (\%), egg weight (g/grain), chicken egg mass ( $\mathrm{g} / \mathrm{head})$ and ration conversion).

\section{Trial Design and Data Analysis}

An experiment was performed in a $5 \times 2$ factorial arrangement using a completely randomized design with 3 replications. Each replication consisted of six laying hens. The first factor was the level of brown seaweed (S.crassifolium) in drinking water (A $1=0.0 \%$ S.crassifolium (control); $\mathrm{A} 2=2.5 \%$ S.crassifolium; A3 $=5.0 \%$ S.crassifolium; $A 4=7.5 \%$ S.crassifolium; A5 $=10.0 \%$ S.crassifolium). The second factor was the presence or absence of antibiotics in feed (B1= feed with additional antibiotics (antibiotics from PT Charoen Pokhand Indonesia), B2=feed without additional antibiotics).

The data were analyzed using analysis of variance followed by Duncan's multiple range test 
and the orthogonal polynomial test (Mattjik \& Sumertajaya, 2002) using the SPSS ${ }^{\circledR} 21.0$ statistical software program.

\section{RESULTS AND DISCUSSION}

\section{Results}

Feed intake, daily egg production, egg weight, egg mass, and feed conversion are presented in Table 2. Levels of uronic acid obtained from $S$. crassifolium and antibiotics did not affect the performance of laying hens, except for feed intake. Feed intake in this study showed a significant difference $(\mathrm{P}<0.05)$ between treatments. The administration of uronic acid to drinking water and the addition of antibiotics in feed provided a real influence on feed intake. Feed intake in treatment A2B2 (117.60 g/head/d) and A1B2 (116.35 g/head/d) were higher than those in the other treatments. The lowest feed intake was observed in treatment A4B1, A3B1, and $\mathrm{A} 2 \mathrm{~B} 1$ at $112.00,112.07$, and $112.30 \mathrm{~g} / \mathrm{head} / \mathrm{d}$, respectively. In general, the highest feed intake was observed in the A2B2 treatment (feed without antibiotics with $2.5 \%$ supplementation of uronic acid extracted from S.crassifolium) (Fig. 1).

Table 2. The average performance of laying hens

\begin{tabular}{|c|c|c|c|c|c|c|c|}
\hline Variable & Factor & A1 & $\mathrm{A} 2$ & A3 & A4 & A5 & Average \\
\hline \multirow{4}{*}{$\begin{array}{l}\text { Feed Intake } \\
(\mathrm{g} / \text { head/d })\end{array}$} & B1 & $\begin{array}{c}114.5 \pm \\
0.80^{c}\end{array}$ & $\begin{array}{c}112.30 \pm \\
2.97^{\mathrm{d}}\end{array}$ & $\begin{array}{c}112.07 \pm \\
0.35^{\mathrm{d}}\end{array}$ & $\begin{array}{c}112.00 \pm \\
2.40^{\mathrm{d}}\end{array}$ & $\begin{array}{c}115.80^{ \pm} \\
0.14^{\mathrm{b}}\end{array}$ & $\begin{array}{c}113.22 \pm \\
2.05\end{array}$ \\
\hline & B2 & $\begin{array}{c}116.35 \pm \\
0.35 \mathrm{a}\end{array}$ & $\begin{array}{c}117.60 \pm \\
0.28 \mathrm{a}\end{array}$ & $\begin{array}{c}114.85 \pm \\
0.64 b\end{array}$ & $\begin{array}{c}114.8 \pm \\
0.99 \mathrm{c}\end{array}$ & $\begin{array}{c}113.85 \pm \\
0.92 \mathrm{c}\end{array}$ & $\begin{array}{c}115.49 \pm \\
1.49\end{array}$ \\
\hline & \multirow{2}{*}{ Average } & $115.24 \pm$ & $114.95 \pm$ & $113.18 \pm$ & $113.12 \pm$ & $114.83 \pm$ & \\
\hline & & 1.17 & 3.51 & 1.58 & 2.34 & 1.25 & \\
\hline \multirow{6}{*}{$\begin{array}{l}\text { Water intake } \\
(\mathrm{mL} / \mathrm{head} / \mathrm{d})\end{array}$} & \multirow{2}{*}{ B1 } & $265.77 \pm$ & $245.73 \pm$ & $272.00 \pm$ & $265.83 \pm$ & $265.17 \pm$ & $262.90 \pm$ \\
\hline & & 23.56 & 42.28 & 20.13 & 19.59 & 32.75 & 26.20 \\
\hline & \multirow{2}{*}{ B2 } & $258.60 \pm$ & $264.47 \pm$ & $246.60 \pm$ & $246.43 \pm$ & $273.13 \pm$ & $257.85 \pm$ \\
\hline & & 14.54 & 6.70 & 10.12 & 18.60 & 14.95 & 15.71 \\
\hline & \multirow{2}{*}{ Average } & $262.18 \pm$ & $255.10 \pm$ & $259.30 \pm$ & $256.13 \pm$ & $269.15 \pm$ & \\
\hline & & 17.94 & 28.96 & 19.91 & 20.12 & 23.18 & \\
\hline \multirow{6}{*}{$\begin{array}{l}\text { Egg } \\
\text { production } \\
(\%)\end{array}$} & \multirow{2}{*}{ B1 } & $96.68 \pm$ & $89.61 \pm$ & $95.95 \pm$ & $92.44 \pm$ & $96.13 \pm$ & $94.16 \pm$ \\
\hline & & 0.98 & 0.82 & 2.56 & 4.11 & 0.88 & 1.87 \\
\hline & \multirow{2}{*}{ B2 } & $97.72 \pm$ & $94.78 \pm$ & $91.21 \pm$ & $95.89 \pm$ & $95.74 \pm$ & $95.07 \pm$ \\
\hline & & 2.10 & 1.85 & 7.26 & 1.56 & 1.76 & 2.91 \\
\hline & \multirow{2}{*}{ Average } & $97.20 \pm$ & $92.20 \pm$ & $93.58 \pm$ & $94.17 \pm$ & $95.94 \pm$ & \\
\hline & & $1.54 \mathrm{a}$ & $1.34 b$ & 4.91ab & $2.84 \mathrm{ab}$ & $1.32 \mathrm{a}$ & \\
\hline \multirow{6}{*}{$\begin{array}{l}\text { Egg weight } \\
\text { (g/grain) }\end{array}$} & \multirow{2}{*}{ B1 } & $57.32 \pm$ & $56.76 \pm$ & $58.74 \pm$ & $57.35 \pm$ & $57.25 \pm$ & $57.48 \pm$ \\
\hline & & 1.94 & 1.46 & 3.37 & 2.36 & 0.98 & 2.02 \\
\hline & \multirow{2}{*}{ B2 } & $58.60 \pm$ & $57.28 \pm$ & $56.52 \pm$ & $55.95 \pm$ & $58.02 \pm$ & $57.27 \pm$ \\
\hline & & 1.17 & 0.87 & 2.49 & 1.32 & 0.41 & 1.25 \\
\hline & \multirow{2}{*}{ Average } & $57.96 \pm$ & $57.02 \pm$ & $57.63 \pm$ & $56.65 \pm$ & $57.64 \pm$ & \\
\hline & & 1.54 & 1.17 & 2.92 & 1.84 & 1.39 & \\
\hline \multirow{6}{*}{$\begin{array}{l}\text { Egg mass } \\
(\mathrm{g} / \mathrm{head})\end{array}$} & \multirow{2}{*}{ B1 } & $51.75 \pm$ & $48.89 \pm$ & $52.06 \pm$ & $50.02 \pm$ & $51.36 \pm$ & $50.82 \pm$ \\
\hline & & 2.77 & 1.74 & 2.29 & 1.73 & 0.75 & 2.07 \\
\hline & \multirow{2}{*}{ B2 } & $54.36 \pm$ & $50.58 \pm$ & $51.72 \pm$ & $51.72 \pm$ & $51.54 \pm$ & $51.62 \pm$ \\
\hline & & 2.31 & 0.39 & 1.38 & 2.66 & 2.41 & 2.32 \\
\hline & \multirow{2}{*}{ Average } & $53.06 \pm$ & $49.74 \pm$ & $50.98 \pm$ & $50.87 \pm$ & $51.45 \pm$ & \\
\hline & & 2.69 & 1.46 & 2.06 & 2.21 & 1.60 & \\
\hline \multirow{6}{*}{$\begin{array}{c}\text { Feed } \\
\text { conversion }\end{array}$} & \multirow{2}{*}{ B1 } & $2.20 \pm$ & $2.30 \pm$ & $2.13 \pm$ & $2.24 \pm$ & $2.18 \pm$ & $2.21 \pm$ \\
\hline & & 0.14 & 0.08 & 0.08 & 0.15 & 0.08 & 0.11 \\
\hline & \multirow{2}{*}{ B2 } & $2.10 \pm$ & $2.27 \pm$ & $2.28 \pm$ & $2.39 \pm$ & $2.16 \pm$ & $2.34 \pm$ \\
\hline & & 0.10 & 0.09 & 0.14 & 0.45 & 0.12 & 0.18 \\
\hline & \multirow{2}{*}{ Average } & $2.15 \pm$ & $2.29 \pm$ & $2.21 \pm$ & $2.55 \pm$ & $2.17 \pm$ & \\
\hline & & 0.12 & 0.08 & 0.11 & 0.30 & 0.10 & \\
\hline
\end{tabular}

$\mathrm{A} 1=0 \%$ Uronic acid (control), $\mathrm{A} 2=2.5 \%$ Uronic acid, $\mathrm{A} 3=5 \%$ Uronic acid, A4 $=7.5 \%$ Uronic acid, A5 $=$ $10 \%$ Uronic acid, B1 = Feed with antibiotic; B2 $=$ Feed without antibiotic. A different superscript in the same row shows a significant difference $(\mathrm{P}<0.05)$ 
The average consumption of drinking water of laying hens $(\mathrm{mL} / \mathrm{head} / \mathrm{d})$ supplemented with different levels of uronic acid extracted from S.crassifolium and feed consumption with and without antibiotics in each treatment did not show significant differences (Table 2). The average consumption of drinking water was higher $(\mathrm{P}<0.05)$ in the A5B2 treatment $(273.13$ $\mathrm{mL} / \mathrm{head} / \mathrm{d})$. This result shows that there was an interaction between feed without antibiotics and the level of uronic acid extracted from S.crassifolium in drinking water although statistically, $10 \%$ uronic acid extracted from $S$. crassifolium in drinking water did not significantly replace the use of antibiotics.
The average production, weight and mass of eggs (\%) from chickens fed with antibiotics and without antibiotics and levels of uronic acid extracted from S. crassifolium in drinking water did not show significant differences, and there was no interaction between treatments. The highest egg production was observed in treatments A4B2 (95.89\%), and A5B2 (95.74\%) and the lowest egg production was observed in A2B1 (89.61\%). The average egg weight in the A3B1 treatment was $58.74 \mathrm{~g} /$ item (Fig. 2). The average egg mass tended to be higher in the A1B2 treatment, which was $576.39 \mathrm{~g} / \mathrm{head}$.

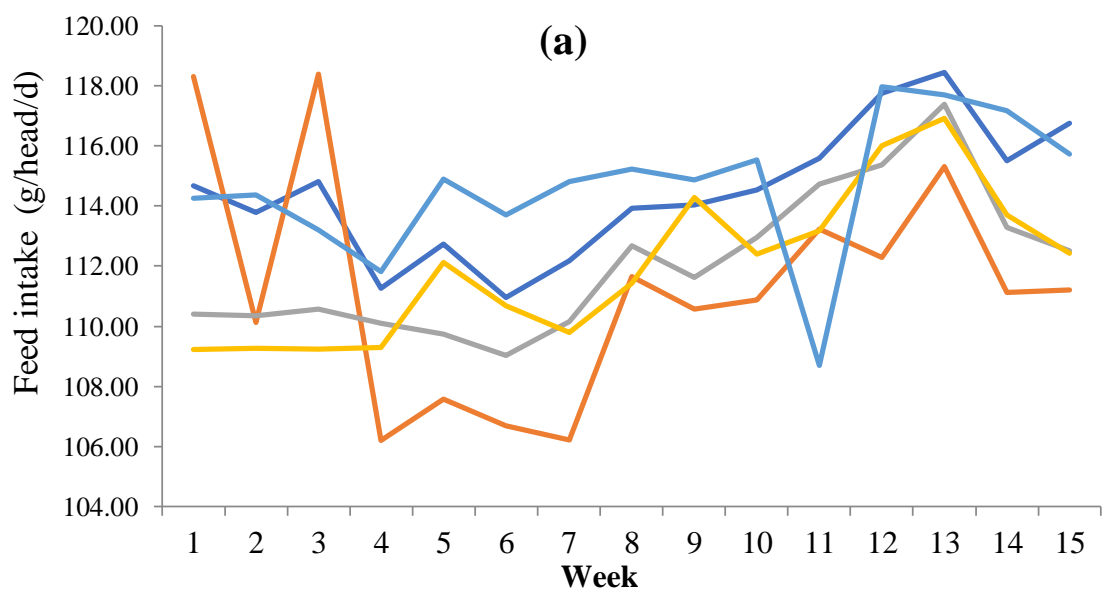

A1-A5 : level of uronic acid from S.crasifolium; B1 : feed with antibiotic
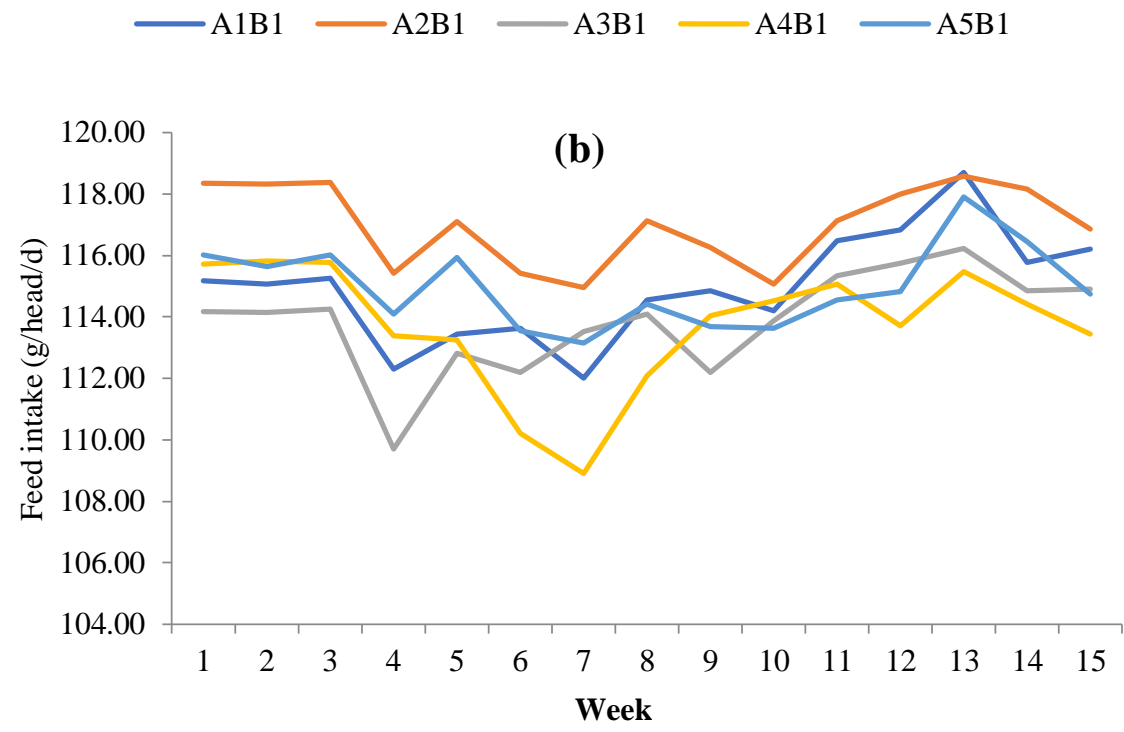

A1-A5 : Level of uronic acid from S.crassifolim;B2 : Feed without

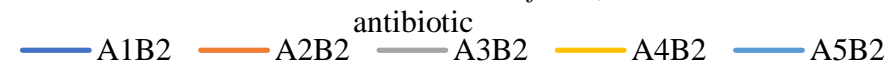

Fig. 1: Feed intake (g/head/d) of Lohmann chickens

(a) Chickens fed with antibiotics; (b) Chickens fed without antibiotics 


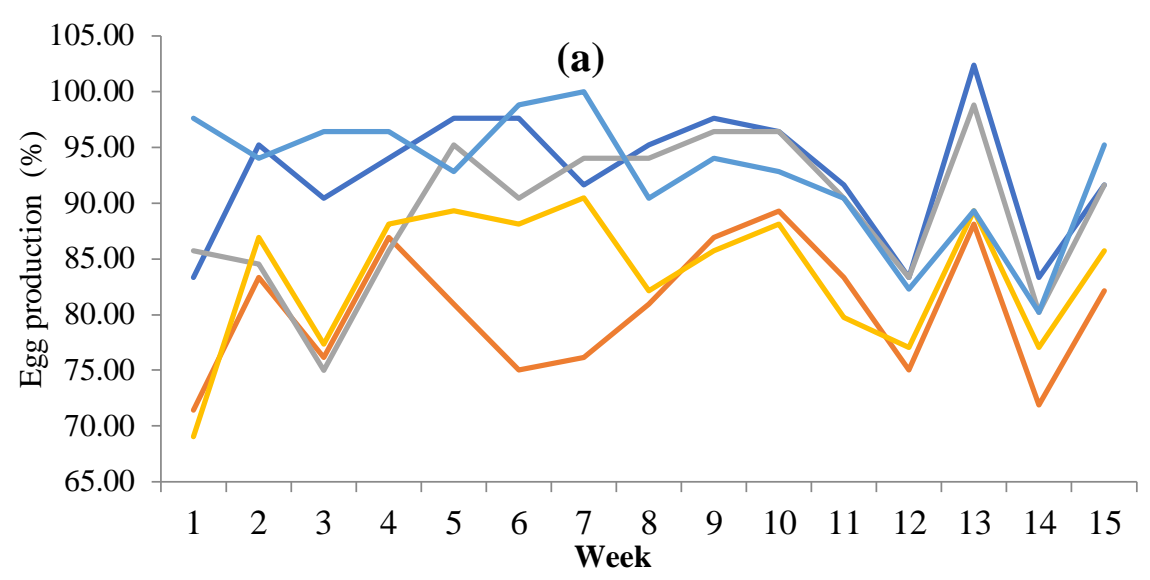

A1-A5 : Level of uronic acid from S.cassifolium; B1 : Feed with A1B1 antibiotic

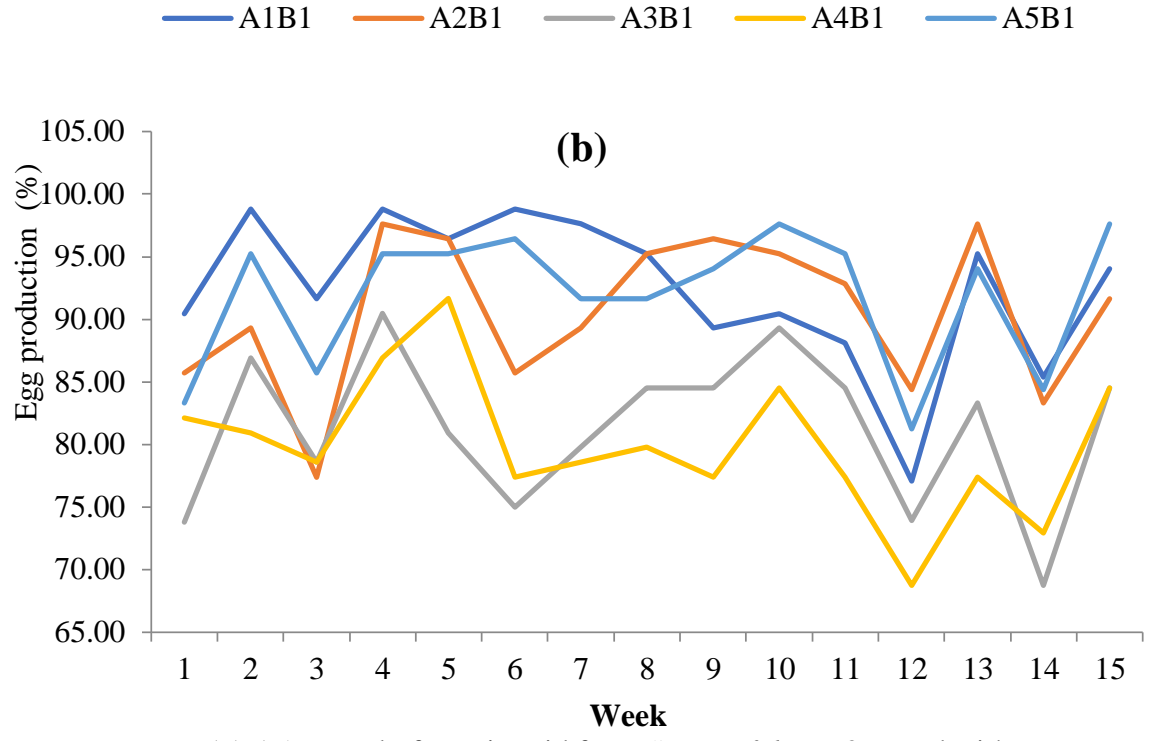

A1-A5 : Level of uronic acid from S.crassifolim; B2 : Feed without antibiotic

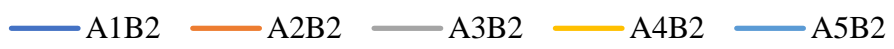

Fig. 2: Egg production (\%) of Lohmann chickens

(a) Chickens fed with antibiotics; (b) Chickens fed without antibiotics

Feed conversion of laying hens $(\%)$ fed feed containing antibiotics and without antibiotics did not show significant differences. The average feed conversion tended to be higher in the $\mathrm{A} 2 \mathrm{~B} 1$ treatment at $2.30 \%$. This result shows that $\mathrm{A} 2 \mathrm{~B} 1$ tends to be less efficient than other treatments.

\section{Discussion}

Generally, feed intake (g/head/d) without antibiotics with a level of uronic acid extracted from $S$. crassifolium in drinking water tended to be higher than feed intake of with antibiotics added group. This finding shows that uronic acid extracted from $S$. crassifolium in drinking water can increase feed intake and cause a smooth digestion process for feed. Zhao et al (2005) stated that S.crassifolium can facilitate food digestion. This study shows that alginate from the uronic acid extracted from $S$. crassifolium probably played an important role in increasing the feed intake of Lohmann chickens. Brownlee et al. (2005) stated that alginate is a soluble fibre that is beneficial in reducing blood glucose levels, reducing toxicity levels of intestinal lumen, reducing microbial colonies that are not beneficial, absorbing toxins in the colon and changing intestinal microflora. These conditions cause the feed absorption process, and the rate of digestive tract emptying to be faster and cause increased feed intake.

The use of uronic acid extracted from $S$. crassifolium in drinking water tends to show the same effect. Daily egg production (\%), egg weight 
(g/grain) and egg mass (g/head) tended to be higher with feed without antibiotics than those with antibiotics. The egg weight observed in this study were higher than those reported by Selim et al (2018) who found egg weights ranging from 40-46 $\mathrm{g}$ using Spirulina platensis as a feed additive to improve egg quality and hepatoprotective activity of laying hens. This result shows that feed intake $(\mathrm{g} / \mathrm{head} / \mathrm{d})$ without antibiotics tended to increase egg weight (g/grain). Egg weight is influenced by many factors, including genetics, maturity stages, age, drugs, food substances in feed, especially amino acids and linoleic acid, and the content of linoleic and methionine fatty acids (Leeson \& Summers, 2005). It was shown that the feed supplement i.e, the level of uronic acid obtained from S.crassifolium, was able to increase egg weight by increasing feed intake.

Although the value of feed intake $(\mathrm{g} / \mathrm{head} / \mathrm{d})$, daily egg production $(\%)$, egg weight (g/grain) and egg mass ( $\mathrm{g} /$ head) tended to be higher in the use of levels uronic acid extracted from S.crassifolium without antibiotics, it did not demonstrate an efficiency in feed conversion. According to Lokapirnasari et al. (2011), a higher FCR means that the use of the feed is less economical. The feed conversion of laying hens ranged from 2.1-2.3. Factors that can influence feed conversion including the physical form of feed, chicken body weight, nutrient content in the ration, maintenance environment, stress, and gender. Feed conversion calculations are intended to determine the ability of chickens to convert the feed consumed into eggs and demonstrate the response of chickens to the quality of feed given (Lokapimasari et al., 2011).

\section{CONCLUSION}

The administration of uronic acid extracted from $S$. crassifolium in drinking water as a substitute for antibiotics has not been able to increase the production and quality of Lohmann chicken eggs.

\section{REFERENCE}

Abaza, I.M. 2007. Effects of using fenugreek, camomile and radish as feed additives on productive performance and digestibility coefficients of laying hens. Poult Sci 27:199-218.

Abbas, T.E. 2013. The use of Moringa oleifera in poultry diets. Turk. J Vet Anim Sci 37:492496.
Abdulhasan, S.D. 2018. Effect of Digestrom® and Poultry Star ${ }^{\circledR}$ on the body performance and immunity status of broiler chickens. Int $\mathbf{J}$ Poult Sci 17:385-391.

Anggadiredja, Hasanudin, A.S. Sidiq, S. Pratomo, \& A. Rudyansyah. 1996. Screening of marine algae from Warambadi seachore Sumba Island of Indonesia for antibacterial activity. Phytomedicine 1996(3):1-37.

Aqil, A.A. 2016. Effect of adding Dietary Fenugreek (Trigonella foenum graecum L.) powder on productive performance and egg quality of laying hens. Int $\mathbf{J}$ Poult Sci 15(7):259-263.

Brownlee, I.A., A. Allen, J.P. Pearson, P.W. Dettmar, M.E. Havler \& M.R. Atherton. 2005. Alginate as a source of dietary fiber. Critical review in Food Science and Nutrition 45:497-510.

Burtin, P, 2003. Nutritional value of seaweeds. Electron. J. Environ Agric Food Chem 2: 498-503

Chandia N.P \& B. Matsuhiro. 2008. Characterization of a fucoidan from Lessonia vadosa (Phaeophyta) and its anticoagulant and elicitor properties. International Journal of Biological Macromolecules 42:235-240.

Choi, Y., E.C. Lee, Y. Na, \& S.R. Lee, 2018. Effects of dietary supplementation with fermented and non-fermented brown algae by-products on laying performance, egg quality, and blood profile in laying hens. Asian-Australas J Anim Sci 00:1-6.

Devegowda, G., B.I.R. Aravind \& M.G. Morton. 1997. Immunosuppression in poultry caused by aflatoxin and its allevation by Saccharommyces cerevisiae (Yea Sacc, 1026) And Mannanoligosacharides. Proc. Alltech 11 Th Annual Asia Pacific Lecture Tour.121-132.

Farhad, A. \& R.A. Farida. 2011. Factor affecting quality and quantiy of egg production in laying hens: A review. World Appl Sci J 12: 372-384.

Gantois, I., R. Ducatelle, F. Pasmans, F. Haesebrouck, R. Gast, T.J. Humphrey, \& F.V. Immerseel. 2009. Mechanisms of egg contamination by Salmonella enteritidis. Federatiom of European Microbiological Societies. Blackwell publishing. Belgium. 
Leeson S \& J. D. Summers. 2005. Commercial poultry nutrition. 3rd Ed. University Books. Ontario (CA).

Lokapirnasari, W.P., Soewarno \& Y. Dhamayanti. 2011. Potensi crude spirulina terhadap protein efisiensi rasio pada ayam petelur. Jurnal Ilmiah Kedokteran Hewan 2:5-8.

Mahfuz, S.U., M.J. Nahar, C. Mo, Z. Ganfu, L. Zhongjun, \& S. Hui. 2017. Inclusion of probiotic on chicken performance and immunity: A review. Int J Poult Sci 16: 328335.

Mandal, P., C.G. Mateu, K. Chattopadhyay, C.A. Pujol, E.B. Damonte, \& B. Ray, 2007. Structural features and antiviral activity of sulphated fucans from the brown seaweed Cystoseira indica. Antiviral Chemistry \& Chemotherapy 18(3):153-162.

March, W., N. Hamid, T. Liu, J. Lu, \& W.L. White. 2013. Fucoidan from New Zealand Undaria Pinnatifida: monthly variations and determination of antioxidant activities. Carbohydrate Polym 95: 606-614.

Mattjik, A.A \& M. Sumertajaya. 2002. Perancangan Percobaan dengan Aplikasi SAS dan Minitab. Ed ke-2. IPB Press. Bogor.

Merdekawati W \& A.B. Susanto. 2009. Kandungan dan komposisi pigmen rumput laut serta potensinya untuk kesehatan. Squalen 4(2):41-47.

Rusli, R.K., K.G. Wiryawan, T. Toharmat, Jakaria, \& R. Mutia. 2015. Supplementation of mangosteen pericarp meal and vitamin $\mathrm{E}$ on egg quality and blood profile of laying hens. Media Peternakan 38(3):198-203.

Santoso, U., Y. Fenita, \& Kususiyah, 2018. The effect of fermented Sauropus androgynus plus bay leaf inclusion on the hematologic and lipid profiles of female broiler chicken. International Journal of Poultry Science. 17(9):1-8.

Selim, S., E. Hussein, \& R. Abou-Elkhair. 2018. Effect of Spirulina platensis as a feed additive on laying performance, egg quality and hepatoprotective activity of laying hens. Europ Poult Sci 82:1-13.
Shiratori, K., K. Ohgami, I. Ilieva, X.H. Jin, Y. Koyama, K. Miyashita, K. Yoshida, S. Kase, \& S. Ohno, 2005. Effect of fucoxanthin on lipopolysaccharide-induced inflammation in vitro and in vivo. Exp Eye Res 81:442-428.

Teteh, A., M. Gbeassor, E. Decuypere, \& K. Tona. 2016. Efects of Moringa oleifera leaf on laying rate, egg quality and blood parameters. Int J Poult Sci 15(7):277-282.

Voemesse, K., A. Teteh, D. Nideou, O. N'nanlé, M. Gbeassor, E. Decuypere, \& K. Tona. 2018. Effect of Moringa oleifera leaf meal on growth performance and blood parameters of egg type chicken during juvenile growth. Int J Poult Sci 17:154-159.

Wijesinghe W.A.J.P. \& Y.J. Jeon. 2011. Enzymeassistant extraction (EAE) of bioactive components: A useful approach for recovery of industrially important metabolites from seaweeds: A review. Fitoterapia 83 (1):6-12.

Winsisch, W., K. Shedle, C. Plitzner, \& A. Kroismayr. 2008. Use of pytogenic product as feed additives for swine and poultry. $\mathbf{J}$ Anim Sci 86:140-148.

Yenusi, T.N.B., A. Sabdono, \& I. Widowati. 2014. Studi komposisi dan potensi antioksidan dari pigmen rumput laut Turbinaria conoides yang berasal dari perairan pantai Hamadi Jayapura Papua. Prosiding Seminar Nasional Kimia dan Pendidikan Kimia VI : "Pemantapan Riset Kimia dan Asesmen dalam pembelajaran Berbasis pendekatan Saintifik" Surakarta, 21 Juni 2014. P.316325.

Zhao, X., C.H. Xue, Y.P. Cai, D.F. Wang \& Y. Fang. 2005. The study of antioxidant activities of fucoidan from Laminaria japonica. High Technology Letters 11:9194. 